Original Research Paper

\title{
The Antinociceptive Effects of Central and Peripheral Administration of Peganum harmala L. Extracts in Animal Models
}

\author{
${ }^{1}$ Rachida Aboufatima, ${ }^{2}$ Loubna Farouk, ${ }^{2}$ Mehdi Ait Laaradia, ${ }^{2}$ Sara Oufquir, ${ }^{2}$ Laadraoui Jawad, \\ ${ }^{2}$ Abderrazak El Alami, ${ }^{2}$ Zineb El Gabbas, ${ }^{2}$ Kenza Bezza, ${ }^{2}$ Fatim Zahra Marhoume, ${ }^{2}$ Zahra Sokar and \\ ${ }^{2}$ Abderrahman Chait. \\ ${ }^{1}$ Laboratory of Génie Biologique, Faculty of Sciences and Techniques, University Sultan Moulay Slimane, Beni Mellal, Morocco \\ ${ }^{2}$ Laboratory of Pharmacology, Neurobiology, Anthropobiology and Environnement, Department of Biology, Faculty of \\ Sciences Semlalia, University Cadi Ayyad, Marrakech, Morocco
}

\author{
Article history \\ Received: 02-10-2020 \\ Revised: 03-12-2020 \\ Accepted: 23-12-2020 \\ Corresponding Author: \\ Abderrahman Chait \\ Laboratory of Pharmacology, \\ Neurobiology, \\ Anthropobiology and \\ Environnement, Department of \\ Biology, Faculty of Sciences \\ Semlalia, University Cadi \\ Ayyad, Marrakech, Morocco \\ Email: chait@uca.ac.ma
}

\begin{abstract}
The medicinal plant Peganum harmala has been used in traditional Moroccan medicine to accelerate the healing process of various diseases and to relieve the pain. The antinociceptive effect of the Aqueous (AE), Dichloromethane (DE) and Butanolic (BE) extracts of the Peganum harmala L. was tested in mice and rats by chemical and thermal models. Plant seed extracts were given intraperitoneally $30 \mathrm{~min}$ before the $0.6 \%$ acetic acid injection. Dichloromethane (DE) at doses of $25 \mathrm{mg} / \mathrm{kg}(68.4 \%$; $\mathrm{p}<0.001), 50 \mathrm{mg} / \mathrm{kg}(79.75 \% ; \mathrm{p}<0.001), \mathrm{AE}$ in doses $25 \mathrm{mg} / \mathrm{kg}(2.65 \%$; $\mathrm{p}>0.05), 50 \mathrm{mg} / \mathrm{kg}(24.39 \% ; \mathrm{p}<0.05)$ and BE in doses $25 \mathrm{mg} / \mathrm{kg}(36.82 \%$; $\mathrm{p}<0.001), 50 \mathrm{mg} / \mathrm{kg}(74.26 \% ; \mathrm{p}<0.001)$ induced decrease in torsional reaction relative to control group. The $\mathrm{DE}, \mathrm{BE}$ and $\mathrm{AE}(25,50 \mathrm{mg} / \mathrm{kg}$, intraperitoneally injection (i.p.,); $60 \mu \mathrm{g} / \mathrm{kg}$, intracerebroventricular injection (i.c.v.,)) extracts of $P$. harmala generated a significant latency increase in the tail-flick response to thermal stimulation and generated a significant increase in the reaction time in the hot plate test. Whereas in formalin test, $\mathrm{DE}, \mathrm{BE}$ and $\mathrm{AE}$ revealed a significant impact on both phases when given by intraperitoneal route. The antinociceptive effect of extracts was lower than morphine $(10 \mathrm{mg} / \mathrm{kg}$, i.p.,) in the hot-plate test and in both the phases of formalin test. Data suggest that extracts of $P$. harmala have inhibitory activity on the mechanisms of peripheral and central pain. Analgesic activity of this plant could potentially be associated with the presence of alkaloids, flavonoids, tannins, saponins and steroids in all P. harmala (Linn) seed extracts. It seems that the reason of popular use to relieve some pains.
\end{abstract}

Keywords: Peganum harmala, Antinociceptive Activity, Writhing Test, Tail Flick Test, Hot Plate

\section{Introduction}

Analgesic drugs are known to have a wide range of side effects. Finding new analgesic drugs whose effects are denied is considered a therapeutic priority.

Medicinal plants and their active compounds are considered a new chemical substance with potentially therapeutic effects (Blumenthal et al., 2000). P. harmala has been an essential herbal medicine since antiquity, known to have many therapeutic activities and also presumed analgesic activity.

$P$. harmala $\mathrm{L}$. belongs to the Zygophyllaceae family commonly known as "Harmal". It is a hairless, perennial plant that grows in sandy soils in pre-desert and semiarid regions (Chemli, 1991). The plant is well known in Morocco and has been widely distributed and applied in North Africa, Central Asia and the Middle East as a medicinal plant. It has also been planted in Australia and America (Chemli, 1991).

In Moroccan traditional medicine, the seeds of $P$. harmala were traditionally used as an infusion, powder or decoction for diarrhea, pain, abortion, rheumatism, fever and used on the skin and subcutaneous tumors (Bellakhdar, 1997; Moloudizargari et al., 2013). Also used for the treatment of lumbago, asthma, jaundice and various other human diseases (Bellakhdar, 1997). 
Several studies published in the literature indicate a wide range of pharmacological properties of its seeds such as anti-inflammatory (Bensalem et al., 2014), antidepressant (Li et al., 2017), monoamine oxidase inhibitors (Herraiz et al., 2010), healing wounds (Derakhshanfar et al., 2010), antibacterial, antifungal and antiviral (Moradi et al., 2017; Olmedo et al., 2017). It is effective in the management of dermatoses (Aslam et al., 2014), Parkinson's disease (Moloudizargari et al., 2013), cytotoxic activity (Bournine et al., 2017; Berrougui et al., 2005) and many human diseases (Li et al., 2017).

Harmine, Harmala, Harmaline, Harmalol and Harman alkaloids are the psychological active ingredients of $P$. harmala seeds, which are also found widely in a variety of herbal medicines (Cao et al., 2007; Herraiz et al., 2010). In the central nervous system, these Harmala alkaloids have a broad spectrum of pharmacological actions, such as an anticonvulsive actions (Loew et al., 1985), tremorogenesis (Poirier et al., 1966) and binding to various receptors, including 5-HT-receptors and the benzodiazepine binding site of GABA-receptors (Lamarre and Puil, 1974; Rommelspacher et al., 1985; 1980). Moreover, these substances also have inhibitory effects on platelet aggregation (Saeed et al., 1993), antioxidant effects (YH et al., 1991) immunodulatory effects and cardiovascular action (Li, 1996).

Earlier phytochemical research has shown that the major constituents of $P$. harmala seeds are alkaloids (especially Harmine, Harman, Harmaline and Harmalol) (Li et al., 2017), which would have a various range of potential applications and pharmacological activities. Currently, many reports have shown the analgesic effect of $P$. harmala seed extracts in animal models after peripheral injection (Farouk et al., 2009; Monsef et al., 2004; Pradeep Kumar et al., 2015). Moreover, the in vivo study of the alkaloid extract of $P$. harmala in rats showed an analgesic effect on the central injection model (Farouk et al., 2008). However, to date, there is no clear evidence for the central effect of peripheral therapy with $P$. harmala extracts on induced pain in several animal models.

The objective of the current study is therefore to examine and compare the analgesic potential effect of $P$. harmala extracted by two injection routes (intraperitoneal and intracerebral) using chemical and thermal nociception models.

\section{Materials and Methods}

\section{Plant Materiel}

The aerial parts and seeds of $P$. harmala $L$. were collected in June 2018 from the province of Marrakesh, Morocco, geographic coordinates $\left(31^{\circ} 43^{\prime} 02.7^{\prime \prime} \mathrm{N}\right.$ $\left.8^{\circ} 06 ' 28.7^{\prime \prime} \mathrm{W}\right)$, in June 2018. The botanical identity of the plant specimen has been certified by the botanist
(Ouhammou Ahmed, Professor in department of biology, Faculty of sciences Marrakech) and the voucher specimen (No: 4229) was deposited in the herbarium of the Biology Department.

\section{Plant Material and Preparation of Extracts}

Seeds of $P$. harmala were dried in laboratory at room temperature $\left(25^{\circ} \mathrm{C}\right)$ and in the shade. After grinding the dried material to a fine powder, $210 \mathrm{~g}$ of powder was placed into Soxhlet apparatus and was extracted in a continuous with methanol at $50-60^{\circ} \mathrm{C}$ for $24 \mathrm{~h}$. Methanolic extract has been concentrated and then separated successively by a series of polar solvents (Hexane; Dichloromethane; Ethyl acetate; Butanol). The resulting extracts were concentrated using a Rotary evaporator. The extraction yield was $6.1,6.7$ and $2.8 \%$ for the Aqueous (AE), Butanolic (BE) and Dichloromethane (DE) extracts, respectively.

\section{Animals}

Adult male Sprague-Dawley rats weighing 250-300 g and adult male mice weighing 25-35 g were used for the experiments. All animals were kept in a room maintained on a $12 \mathrm{~h}$ light/dark cycle and temperature controlled $\left(25^{\circ} \mathrm{C}\right)$. The animals had free access to food and water throughout all the experiments. The animals were randomly divided into several groups, 6 animals per group of rats and 8 animals per group of mice, after one week of adaptation.

All experiments included in this study were conducted in accordance with approved institutional protocols and the provisions for animal care and use described in the scientific procedures on live animals ACT 1986 (European Council Directive: 86/609/EEC).

\section{Drugs}

Drugs used are: Acetic acid, ketamine, 2 and 10\% formalin. The dichloromethane, butanol and aqueous extracts of $P$. harmala, Acetylsalicylic Acid (ASA) and morphine were dissolved in normal saline $(0.9 \% \mathrm{w} / \mathrm{v}$ of $\mathrm{NaCl})$. Immediately prior to the start of the experiments, all drug solutions were prepared. The intraperitoneal injection (i.p.,) was carried out with a volume of $0.1 \mathrm{~mL} / 10 \mathrm{~g}$ body weight and intracerebroventricular injection (i.c.v.) was performed using a volume $3 \mu \mathrm{L}$.

\section{Phytochemical Screening}

Standard screening tests were used to screen plant extracts for various constituents. Standard protocol for the determination of the presence of flavonoids (Debray et al., 1971), tannins (Trease and Evans, 1983), steroids and terpenes (Odebiyi and Sofowora, 1978), alkaloids (Rizk et al., 1982), quinones (Mabika, 1983) and saponins (Paris and Moyse, 1965). 


\section{Test for Anthraquinones}

Benzene was added $10 \mathrm{~mL}$ to $6 \mathrm{~g}$ of the sample of ephedra powder in a conical flask, soaked for $10 \mathrm{~min}$ and then filtered. Additional $10 \mathrm{~mL}$ of a $10 \%$ ammonia solution was added to the filtrate and shaken vigorously for $30 \mathrm{sec}$ and a pink, purple or red color indicated the presence of anthraquinones in the ammonia phase.

\section{Test for Tannins}

Ten milliliters of brominated water were added to 0.5 grams of aqueous extract. Decoloration of the bromine water showed the presence of tannins.

\section{Test for Saponins}

Distilled water $(5.0 \mathrm{~mL})$ was mixed with aqueous crude plant extract in a test tube and mixed vigorously. Moss was mixed with a few drops of olive oil and vigorously stirred and the appearance of the moss indicated the presence of saponins.

\section{Tests for Flavonoids}

Fragments of magnesium ribbon and $\mathrm{Hcl}$ concentrate were mixed with aqueous crude plant extract after a few minutes and the pink color indicated the presence of flavonoids.

\section{Test for Terpenoids}

A total of $2.0 \mathrm{~mL}$ of chloroform was added with 5 $\mathrm{mL}$ of aqueous plant extract and boiled with $3 \mathrm{~mL}$ of concentrated $\mathrm{H} 2 \mathrm{~S} 04$ in the water path. The result was a gray color that revealed the entity of terpenoids.

\section{Test for Steroids}

The $5 \mathrm{~mL}$ crude aqueous plant extract was supplemented with $2 \mathrm{~mL}$ of chloroform and concentrated $\mathrm{H} 2 \mathrm{SO} 4$. A red color appeared in the lower layer of chloroform, suggesting the presence of steroids.

\section{Surgical Preparation and Technique of Intracerebroventricular Injection}

The rats were anesthetized with chloral hydrate $(0,6 \mathrm{~g} / \mathrm{kg})$ and implanted stereotaxically with a cannula that descended into the lateral ventricle and was fixed on the skull (coordinates: $1.3 \mathrm{~mm}$ posterior to the bregma, lateral $1.6 \mathrm{~mm}$ from midline, deep 3.2 $\mathrm{mm}$ from the dura). The coordinates were set according to the atlas of (Paxinos and Watson, 2006), with the bregma as the point of reference. All animals were given 10 days to recover after surgery. During this period of time, the animals were handled daily.

Intracerebroventricular injections were made into the lateral ventricle through an injection cannula $(0.15$ $\mathrm{mm}$ inner diameter) using a 30-gauge needle attached to a $10 \mu \mathrm{L}$ Hamilton syringe by PE-10 tubing. The injection volume was $3 \mu \mathrm{L}$.

\section{Tail Flick Test}

The antinociceptive effect was evaluated in a tailimmersion test. The tail of the rat was thrown into a recipient filled with warm water maintained at a stable temperature $\left(55 \pm 2^{\circ} \mathrm{C}\right)$. The delay time before the tail was retracted was recorded in $n=6$ rats by means of a chronometer before the injection, 15, 30, 45, 60, 90, 120, 180 and $240 \mathrm{~min}$. after the injection.

Dichloromethane, aqueous or butanolic extracts (25, $50 \mathrm{mg} / \mathrm{kg}$ ) were administered IP and $60 \mu \mathrm{g} / \mathrm{kg}$ of dichloromethane, aqueous or butanolic extracts were administered i.c.v.

The inhibition of tail-flick response was expressed as "Percent Maximum Possible Effect (\%MPE)" which was calculated as $[(\mathrm{T} 1-\mathrm{T} 0) / \mathrm{T} 2-\mathrm{T} 0)]^{*} 100$. T0 and $\mathrm{T} 1$ was the tail-flick latency before and after the injection respectively, whereas $\mathrm{T} 2$ was the cut-off time which was set at $10 \mathrm{~s}$.

\section{Hot-Plate Test}

Animals were screened by placing them on a hotplate maintained at $55 \pm 1{ }^{\circ} \mathrm{C}$ and the reaction time in seconds for hind paw licking or jumping were recorded (Turner and Hebban, 1965). The latency time taken by the animal to lick one of its legs or to jump is noted and considered as the reaction time. This time was determined at time 0 (just before the injection of the extract) and $30 \mathrm{~min}$ after intraperitoneal administration or $10 \mathrm{~min}$ after intracerebroventricular administration of the extract. A latency period of $30 \mathrm{~s}$ was defined as complete analgesia as cut off time to prevent damage to mice (Paulino et al., 2003).

The animals received Different Extracts (DE, BE and AE) of $P$. harmala at doses $(25$ and $50 \mathrm{mg} / \mathrm{kg}$; i.p; 30 and $60 \mu \mathrm{g} / \mathrm{kg}$, i.c.v), saline solution $(10 \mathrm{~mL} / \mathrm{kg}$, i.p; 3 $\mu \mathrm{L} / \mathrm{rat}$, i.c.v), acetylsalicylic acid (200 $\mathrm{mg} / \mathrm{kg}$, i.p.) or morphine (10 $\mathrm{mg} / \mathrm{kg}$, i.p.).

\section{Acetic Acid-Induced Writhing in Mice}

The antinociceptive effect was evaluated by the writhing test (Collier et al., 1968) induced, in mice ( $n=$ $8)$, by acetic acid $0.6 \%(0.1 \mathrm{~mL} / 10$ g, i.p.). Writhing was characterized by contractions of the abdominal muscles accompanied by extension of the hind limbs.

The dichloromethane, butanolic and aqueous extracts $(25,50 \mathrm{mg} / \mathrm{kg})$, acetylsalicylic acid $(200 \mathrm{mg} / \mathrm{kg})$, or vehicle was injected i.p. $30 \mathrm{~min}$ before the nociceptive agent. Five minutes after the acid administration, the number of writes was recorded for a period of $30 \mathrm{~min}$. The percentage inhibition was determined for each group as follows. 
$\%$ Inhibition $=100 *(1-$ No. of Writhing in the

Experimental Group/No. of Writhing in the Control Group)

\section{Formalin Test in Mice}

Twenty microliters of $2 \%$ formalin solution $(0.9 \%$ formaldehyde) was injected intraplantarly (i.pl.) under the ventral surface of the right hind paw. The animals were placed individually in clear plexiglass chamber $(50 \times 30 \times 25$ $\mathrm{cm}$ ) and observed from 0 to $30 \mathrm{~min}$ following formalin injection according to the method of (Santos et al., 1998). The time spent licking the injected leg was measured and was regarded as an indicator of nociception. Nociceptive behavior was quantified in two phases: The early phase, which normally peaks $5 \mathrm{~min}$ after formalin injection and 15 to $30 \mathrm{~min}$ after formalin injection; the late phase, which represents the tonic and inflammatory responses to pain, respectively (Hunskaar and Hole, 1987). Animals were pretreated intraperitoneally with morphine $(10 \mathrm{mg} / \mathrm{kg})$ and acetylsalicylic acid ASA $(200 \mathrm{mg} / \mathrm{kg})$, used as positive control, or with the various extracts (DE, BE or AE) of $P$. harmala at doses 25 or $50 \mathrm{mg} / \mathrm{kg}, 0.5 \mathrm{~h}$ beforehand. The control animals received the same volume, $0.9 \%$ of $\mathrm{NaCl}$ $(10 \mathrm{~mL} / \mathrm{kg}$, i.p. $)$ used to dilute these drugs. Following intraplantar injection of formalin, each animal was immediately placed into a clear plexiglass chamber and the time it spent licking the injected paw was determined.

\section{Histological Control}

The last step is to confirm the intracerebral injection. The rats were anesthetized with chloral hydrate and infused intracardially with $0.9 \%$ saline followed by $10 \%$ formalin solution. The brains were dissected and fixed in $10 \%$ formalin for 2 days, cut at $20 \mu \mathrm{m}$ thickness and observed under light microscopy for visualization of the cannula induced tissue wound.

\section{Statistical Analysis}

All data are reported as mean \pm Standard Error of the Mean (SEM) and were subjected to a unidirectional analysis of variance (ANOVA). The post-hoc differences between group means were examined by the Tukey test. Results with $\mathrm{p}$ values less than 0.05 were considered statistically significant $\quad(* \mathrm{p}<0.05 ; \quad * * \mathrm{p}<0.01$; $* * * \mathrm{p}<0.001)$. Data analyses were conducted using Sigma Plot v. 12.5 for Windows.

\section{Results}

\section{Phytochemical Screening}

Phytochemical screening of the dichloromethane, butanolic and aqueous extracts of $P$. harmala used in the pharmacological test showed the presence of alkaloids, flavonoids, tannin, sterols, saponins and anthraquinones.

\section{Tail Flick Response}

Intraperitoneal Injections of $D E, B E$ and $A E$ of $P$. Harmala

Aqueous, butanolic or dichloromethane extracts from $P$. harmala seeds induced a dose dependant inhibitory effect on the nociceptive reaction elicited in the tail flick test when compared to vehicle injections. The maximal effect (peak) and the time course of this effect depended on the dose. Intraperitoneal injection of the dichloromethane extract increased significantly the latency to tail with-drawl $(p<0.001)$. This increase developed rapidly and reached peaks of $32.66 \pm 10.17 \% \mathrm{MPE}$ at $120 \mathrm{~min}$ and $37.46 \pm 12.15$ $\%$ MPE at $180 \mathrm{~min}$ for the doses of 25 and $50 \mathrm{mg} / \mathrm{kg}$ respectively (Fig. 1A).

The butanolic extract at the dose of $50 \mathrm{mg} / \mathrm{kg}$ also increased significantly the latency of the nociceptive responses $(\mathrm{p}<0.001)$. The peak for $50 \mathrm{mg} / \mathrm{kg}(\% \mathrm{MPE})$ was in a similar value as that of the same dose of aqueous extract $36.45 \pm 5.1$ at $120 \mathrm{~min}$ (Fig. 1B). Aqueous extract enhanced significantly the latency to tail flick reaction $(p<0.01)$. The time course of this effect developed slowly then reached peaks of $22.18 \pm 2.93 \% \mathrm{MPE}$ at $60 \mathrm{~min}$ and of $33.45 \pm 24.35 \% \mathrm{MPE}$ at $120 \mathrm{~min}$ for $25,50 \mathrm{mg} / \mathrm{kg}$ respectively (Fig. 1C). The duration of the antinociceptive effect lasted less for the dose of $25 \mathrm{mg} / \mathrm{kg}$ (Fig. 1C).

However, the maximal effects of all these extracts didn't reach the values of the maximal effect elicited by the well-known peripheral analgesic drug, acetyl salicylic acid, at the dose of $200 \mathrm{mg} / \mathrm{kg}$. Indeed, the peak of the action of this drug was of $76.06 \pm 10.61 \% \mathrm{MPE}$ at $90 \mathrm{~min}$ and lasted for a longer period $(4 \mathrm{~h})$.

\section{Intracerebroventricular Injections of $D E, B E$ and AE Extracts of P. harmala}

Intracerebroventricular injections of dichloromethane, butanolic and aqueous extracts of $P$. harmala seeds at the dose of $60 \mu \mathrm{g} / \mathrm{kg}$ produced a significant inhibition of the tail flick response when compared to the vehicle injection (Fig. 2).

The antinociceptive effect of the aqueous extract started at the first min after administration then reached a peak of $28.70 \pm 12.78 \% \mathrm{MPE}$ at $45 \mathrm{~min}$. This effect remained significant until $90 \mathrm{~min}(\mathrm{p}<0.001)$. The inhibitory effect of dichloromethane was also significant $(p<0.05)$ with a maximal effect of $18.47 \pm 11.36 \%$ MPE at $45 \mathrm{~min}$. This effect was different from control until 120 min. The butanolic extract has a less marked effect than the other extracts. The antinociceptive effect started later at $30 \mathrm{~min}$ and has a weaker peak at $45 \mathrm{~min}$ $(14.79 \pm 10.11 \% \mathrm{MPE})$. However, this effect was significant until the $120 \min (\mathrm{p}<0.05)$. 

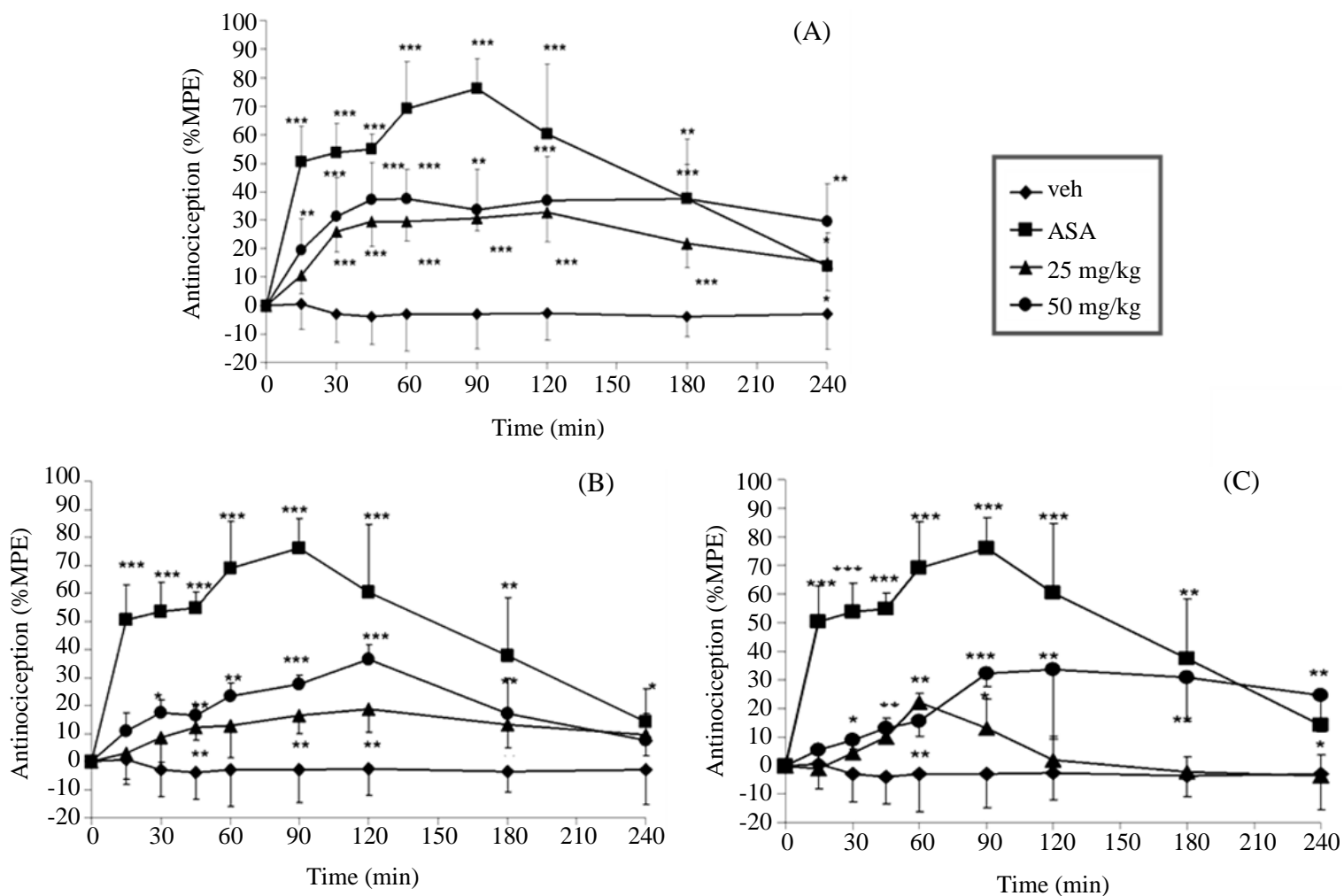

Fig. 1: Time course of change of the Tail-flick response after intraperitoneal administration of dichloromethane (A), Butanolic (B) and aqueous (C) extracts of Peganum harmala L. seeds. Saline solution and Acetylsalicylic Acid (ASA) were used as negative and positive controls, respectively. The inhibition of tail-flick response was expressed as "Percent Maximum Possible Effect $(\% \mathrm{MPE})$ ", which was calculated as $\left[\left(\mathrm{T}_{1}-\mathrm{T}_{0}\right) /\left(\mathrm{T}_{2}-\mathrm{T}_{0}\right)\right] \times 100$. $\mathrm{T}_{0}$ and $\mathrm{T}_{1}$ were the tail-flick latencies before $(0$ min) and after (15, 30, 45,60, $90 \mathrm{~min}, 1,2,3$ and $4 \mathrm{~h})$ injection, whereas $\mathrm{T}_{2}$ was the cut-off time, which was set at $10 \mathrm{~s}$

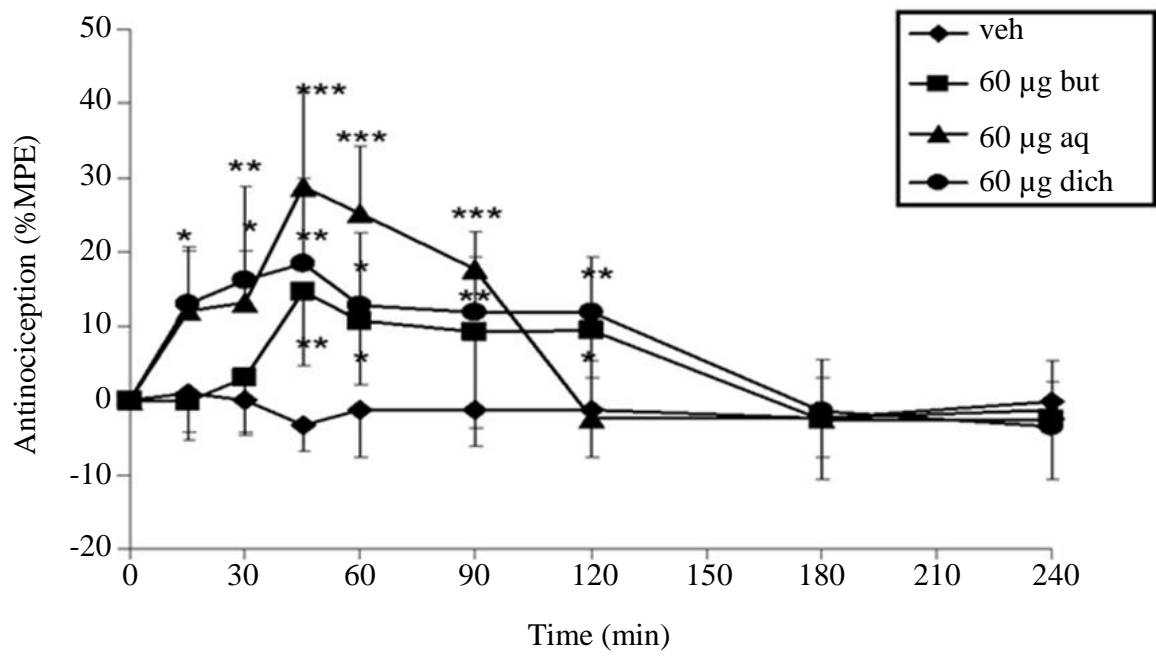

Fig. 2: Time course of change of the Tail-flick response after intracerebroventricular injection of dichloromethane (dich), butanolic (but) and aqueous (aq) extracts of Peganum harmala L. seeds. Saline solution and Acetylsalicylic acid were respectively used as negative and positive controls. The inhibition of tail-flick response was expressed as "Percent Maximum Possible Effect (\%MPE)", which was calculated as $[(\mathrm{T} 1-\mathrm{T} 0) /(\mathrm{T} 2-\mathrm{T} 0)] \times 100 . \mathrm{T}_{0}$ and $\mathrm{T}_{1}$ were the tail-flick latencies before $(0 \mathrm{~min})$ and after $(15,30,45,60,90 \mathrm{~min}, 1,2,3$ and $4 \mathrm{~h})$ injection, whereas $\mathrm{T}_{2}$ was the cut-off time, which was set at $10 \mathrm{~s}$. Each column represents the mean and the vertical bar represents the S.E.M. with sex to eight rats per group 


\section{Hot-Plate Test}

Results of the hot plate test are shown in (Tables 1 and 2). Administration of $\mathrm{DE}(\mathrm{p}<0.001), \mathrm{AE}(\mathrm{p}<0.01)$ and $\mathrm{BE}(\mathrm{p}<0.05)$ of $P$. harmala $(50 \mathrm{mg} / \mathrm{kg}$, i.p.; and 60 $\mu \mathrm{g} / \mathrm{kg}$, i.c.v. $)$ and morphine $(10 \mathrm{mg} / \mathrm{kg}$, i.p., $\mathrm{p}<0.001)$ increased significantly the response time to the nociceptive reaction in the hot plate test.

\section{Writhing Test}

Dichloromethane, butanolic or aqueous extracts of $P$. harmala seeds injected IP decreased significantly the number of acetic acid-induced writhes in mice when compared to their controls. The percent of reduction induced by the aqueous extract depended of the dose and were $2.65 \%$ for $25 \mathrm{mg} / \mathrm{kg}(\mathrm{P}>0.05)$ and $24.39 \%$ for 50 $\mathrm{mg} / \mathrm{kg}(\mathrm{p}<0.05)$ (Fig. 3C). Intraperitoneal injections of the dichloromethane extract were more potent in reducing the nociceptive effect. Thus, these reductions were $68.4 \%$ for $25 \mathrm{mg} / \mathrm{kg}(\mathrm{p}<0.001)$ and $79.75 \%$ for 50 $\mathrm{mg} / \mathrm{kg}(\mathrm{p}<0.001)$ (Fig. 3A). The percentage inhibition on writhing produced by the butanolic extract ( 25 and 50 $\mathrm{mg} / \mathrm{kg}$ ) were 36.82 and $74.26 \%$ respectively (Fig. 3B).
The potency of $50 \mathrm{mg} / \mathrm{kg}$ of dichloromethane extract shown to be similar to that of $200 \mathrm{mg} / \mathrm{kg}$ acetyl-salicylic acid $(65.5 \%)$.

\section{Formalin Test}

Intraplantar injection of formalin (2\%) evoked a biphasic licking response. The effect of DE, BE and $\mathrm{AE}$ of $P$. harmala $L$. in early phase (0-5 min) and late phase (15-30 min) of formalin test are displayed in (Fig. 4). The time of licking for the early phase was $85,48 \pm 9,36$ $\mathrm{s}$ and the late phase was $122,63 \pm 10,21 \mathrm{~s}$ in control groups (Fig. 4). Extracts administered intraperitoneally showed a marked inhibition of inflammatory (late phase) and neurogenic (early phase) pain in a dose-dependent manner. In the tests, for reference, ASA $(200 \mathrm{mg} / \mathrm{kg}$, (i.p.)) provoked a marked inhibition of licking reactions only on the second phase of pain induced by formalin. In contrast, the morphine treatment of the animals (10 $\mathrm{mg} / \mathrm{kg}$, (i.p.)) yielded a marked inhibition of both neurogenic (early phase) and inflammatory pain (late phase) in the formalin test (Fig. 4).
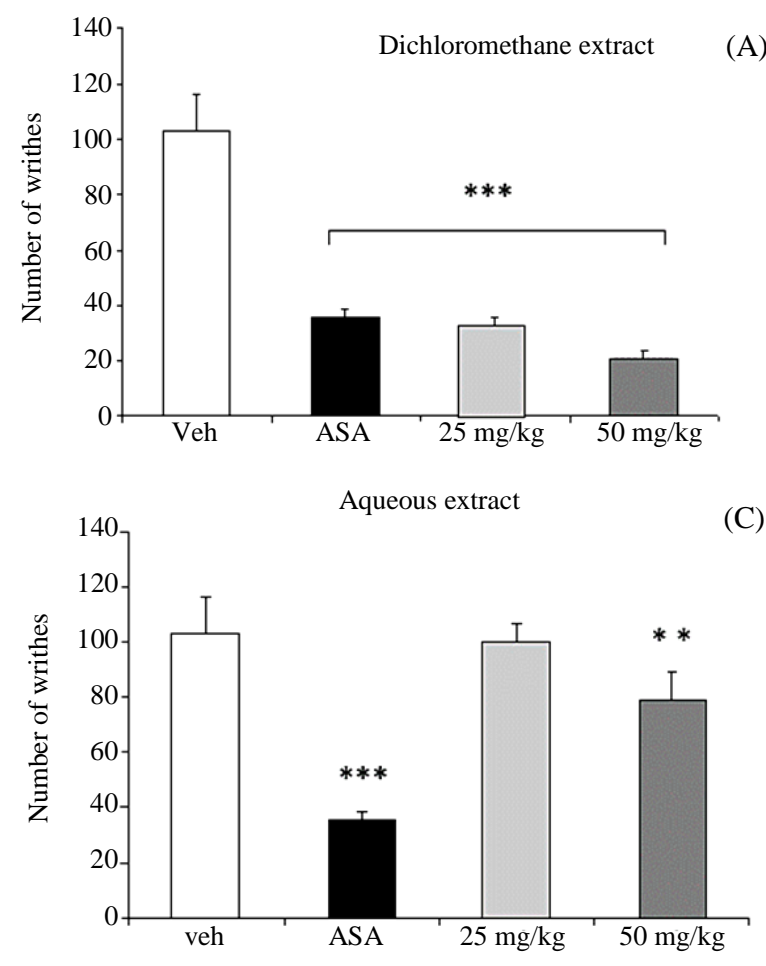

(A)

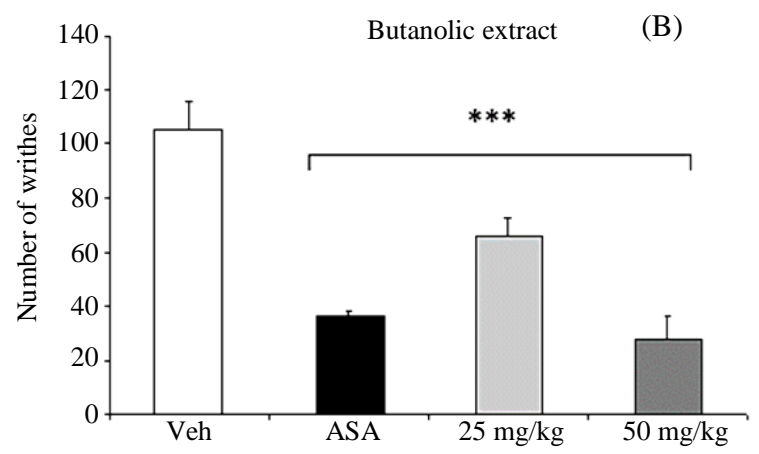

Fig. 3: Effects of dichloromethane and aqueous extracts of Peganum harmala L. seeds on writhing responses induced with the acetic acid: (A): $(25,50 \mathrm{mg} / \mathrm{kg})$ of dichloromethane extract (B): $(25,50 \mathrm{mg} / \mathrm{kg})$ of butanolic extract and (C): Various doses of aqueous extract were administered intraperitoneally $(25,50 \mathrm{mg} / \mathrm{kg}) .30 \mathrm{~min}$ after treatment, an intraperitoneal injection was made of a $0.6 \%$ acetic acid solution $(0.1 \mathrm{~mL} / 10 \mathrm{~g})$. The count of contortions was counted $30 \mathrm{~min}$ after the injection of acetic acid 
(A)

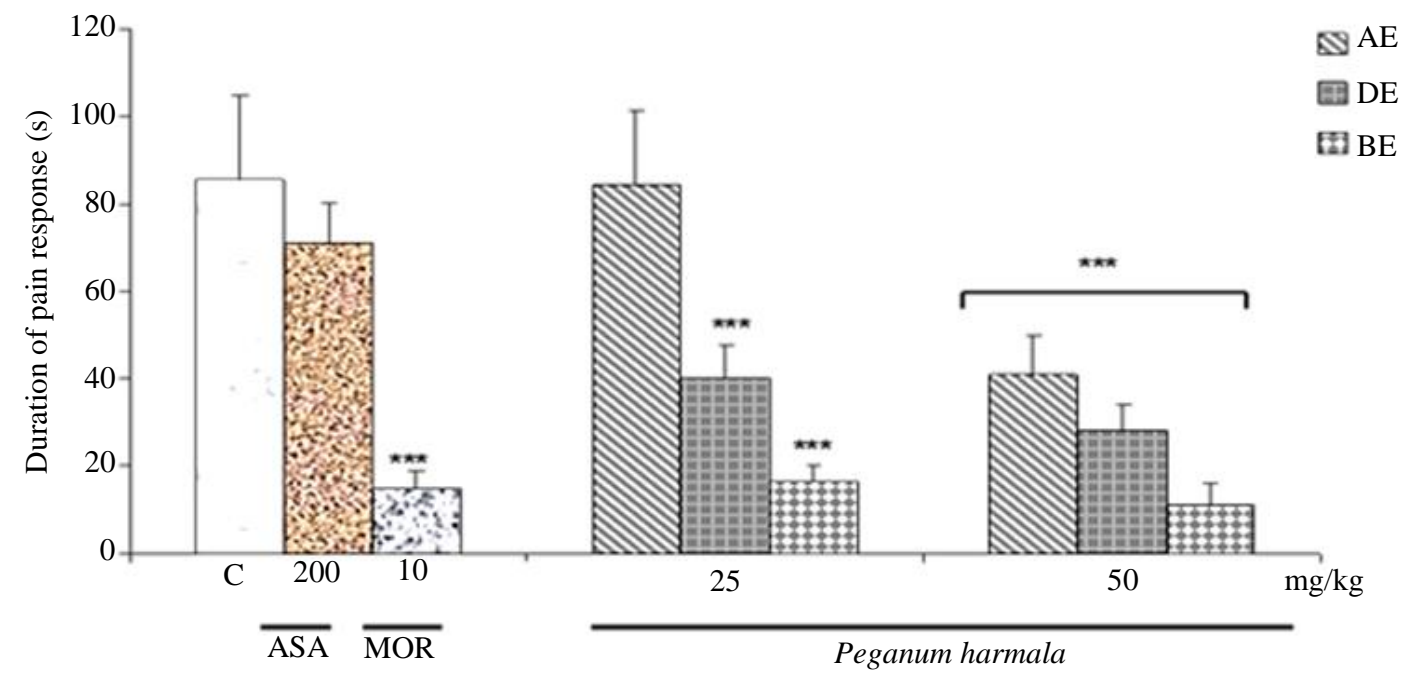

(B)

The late phase

NA AE

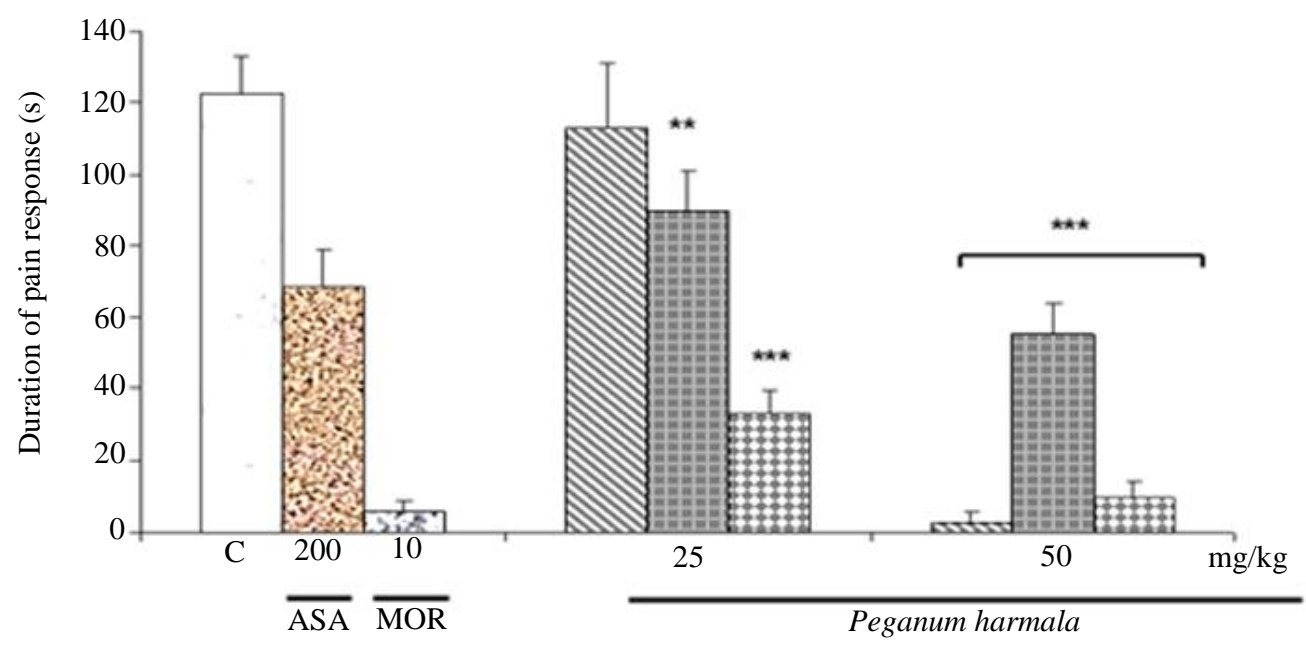

Fig. 4: Effect of dichloromethane (DE), Butanol (BE) and Aqueous (AE) extracts of Peganum harmala L. on the Early (A) and Late (B) phases of the formalin test. Histograms represent \pm S.E.M. means for eight mice $((* \mathrm{p}<0.05),(* * \mathrm{p}<0.01)$ and $(* * * \mathrm{p}<0.001))$ compared to normal saline). Control (C); DE, BE, AE.

Table 1: Effect of intraperitoneal injection (i.p.) of Dichloromethane (DE), Butanolic (BE) and Aqueous (AE) extracts of Peganumharmala on hot-plate reaction time in mice. Results are presented as mean $\pm \mathrm{SEM} ; * \mathrm{P}<0.05 ; * * \mathrm{P}<0.01 ; * * *$ $\mathrm{P}<0.001 \mathrm{Vs}$. Control

\begin{tabular}{llll}
\hline & & Time after treatment (min) & \\
Treatment (i.p.) & Dose $(\mathrm{mg} / \mathrm{kg})$ & 0 & $8.36 \pm 0.97$ \\
Control & - & $8.84 \pm 1.09$ & $9.51 \pm 1.01^{*}$ \\
DE & 25 & $8.84 \pm 1.05$ & $12.09 \pm 2.03^{* *}$ \\
& 50 & $8.80 \pm 0.84$ & $11.16 \pm 1.68^{* *}$ \\
BE & 25 & $8.38 \pm 1.02$ & $12.99 \pm 1.72^{* * *}$ \\
& 50 & $9.41 \pm 1.45$ & $9.79 \pm 1.28^{*}$ \\
AE & 25 & $8.54 \pm 0.70$ & $11.55 \pm 1.59^{* * *}$ \\
& 50 & $9.06 \pm 0.71$ & $18.60 \pm 2.09^{* * *}$ \\
\hline
\end{tabular}


Table 2: Effect of intracerebroventricular injection (i.c.v.) of Dichloromethane (DE), Butanolic (BE) and Aqueous (AE) extracts of Peganum harmala on hot plate reaction time in mice. Results are presented as mean $\pm \mathrm{SEM} ; * * \mathrm{P}<0.01 ; * * * \mathrm{p}<0.001 \mathrm{Vs}$. Control

\begin{tabular}{llll}
\hline & & Time after treatment $(\min )$ & \\
Treatment (i.c.v.) & Dose $(\mu \mathrm{g} / \mathrm{kg})$ & 0 & 10 \\
\hline Control & - & $5.27 \pm 0.39$ & $5.10 \pm 0.58$ \\
$\mathrm{DE}$ & 30 & $5.13 \pm 0.46$ & $5.05 \pm 0.50$ \\
& 60 & $5.03 \pm 0.54$ & $7.62 \pm 0.62^{* * *}$ \\
$\mathrm{BE}$ & 30 & $5.22 \pm 0.65$ & $5.45 \pm 0.99$ \\
& 60 & $4.70 \pm 0.81$ & $7.33 \pm 1.53^{* * *}$ \\
$\mathrm{AE}$ & 30 & $4.53 \pm 0.55$ & $5.62 \pm 1.34$ \\
& 60 & $4.60 \pm 0.89$ & $5.59 \pm 1.32$ \\
\hline
\end{tabular}

\section{Discussion}

The current study showed that the administration of the Aqueous (AE), Butanolic (BE) and Dichloromethane (DE) extracts of $P$. harmala $L$. seeds by intraperitoneal or intracerebral route to animals, generates significant antinociceptive action against chemical (Writhing and formalin tests) and thermal (hot plate tests and tail-flick) models of nociception in rats and mice.

This work shows that the intraperitoneal injection of $\mathrm{DE}, \mathrm{BE}$ and $\mathrm{AE}$ extracts of $P$. harmala seeds results a significant dose-dependent antinociception derived from the evaluation of acetic acid-induced abdominal constrictions, a model employed to assess the potential analgesic activity of substances. Acetic acid has been proposed for action by releasing endogenous mediators to boost nociceptive neurons (Collier et al., 1968). It has been reported to be sensitive to NSAIDs (non-steroidal anti-inflammatory drugs) (Collier et al., 1968, Santos et al., 1998; Reichert et al., 2001). The present study results support earlier data in the literature by confirming that ASA (NSAIDs) causes significant inhibition of acetic acid-induced pain. The method is not just simple and reliable, but also permits rapid assessment of the peripheral type of analgesic action. There is evidence that abdominal constriction is related to sensitization of nociceptive prostaglandin receptors and increased levels of PGE2 and PGF2a in peritoneal fluid (Deraedt et al., 1980). It is hence a possibility that $P$. harmala produced an analgesic effect, probably caused by the suppression of synthesis or by the action of prostaglandins. A number of mediators including kinin, acetylcholine, substance $\mathrm{P}$ and prostaglandins are involved in the nociception of the visceral pain model (Vogel and Vogel, 1997) and the transmission of nociception from the viscera (Cervero and Larid, 1999).

In the tail flick test, our results show that the extracts of $P$. harmala have the ability to prolong the latency of response which indicates an increase in the nociceptive threshold. Seemingly, this effect is strongly dependent on endogenous opioids (Tornos et al., 1999). This test has proven to be appropriate for the assessment of centrally acting analgesic and indicated that the pharmacological actions were aided by mu $(\mu)$ opioid receptors rather than kappa $(\kappa)$ and delta $(\delta)$ receptors (Schmauss and Yaksh, 1984; Aydin et al., 1999). In addition, (Grumbach, 1966) demonstrated that the efficacy of the analgesic drug in models of tail-biting pain is significantly correlated with human pain relief.

The extracts of $P$. harmala provided a strong protective effect on painful chemical (acetic acid injection) and thermal (tail strike) stimuli. The efficacy on these two stimuli is typical of central analgesics, like morphine, which inhibits both inflammatory and noninflammatory pain (Piccinelli and Silvestrini, 1969). Therefore, the extracts seem to have similar effects to those of morphine, which explains the antinociceptive effects on the CNS noted in this study. Data currently available indicate clearly that extracts of $P$. harmala $L$. have a dose dependent peripheral and central potent antinociceptive effect.

The differences between the actions of the extracts of $P$. harmala in the analgesic response may be due in part to changes in the polarity and chemical nature of compounds found in the used extracts following our differential extraction process.

Our results indicated that the time required to lick the injured leg was reduced significantly following intraperitoneal administration of butanol, aqueous and dichloromethane extracts in the first and last phases of the test with formalin. The intraplantation injection of $2 \%$ formalin showed a biphasic licking response characteristic of early and late phase in this test. Drugs that primarily function on the central nervous system, like narcotics, inhibit both phases equally, while drugs that act peripherally inhibit the late phase (Shibata et al., 1989; Chen et al., 1995). The early phase is likely the direct consequence of stimulation of leg nociceptors, while the later phase is due mainly to inflammation with release of histamine, bradykinin, serotonin and prostaglandins (Tjølsen et al., 1992) and at a minimum sensitization of central nociceptive neurons (Coderre et al., 1990; Coderre and Melzack, 1992; Tjølsen et al., 1992). The test is a highly useful method not only for assessing antinociceptive drugs but also to clarify the mechanism 
of action (Shibata et al., 1989). The results of the present study also showed that morphine, but not ASA, is strongly effective in preventing both the early and late phases of the pain induced by formaldehyde. Additional research studies showed that formaldehyde releases various inflammatory mediators (Hunskaar et al., 1986; Hunskaar and Hole, 1987; Santos and Calixto, 1997). However, ASA (a non-steroidal anti-inflammatory drug) is not effective during the early phase of the pain induced by formaldehyde. NSAIDs, such as indomethacin, acetaminophen and diclofenac, known to inhibit Cyclo-Oxygenase (COX) activity and they are ineffective or cause very little inhibition during the early phase of formaldehyde testing. (Hunskaar and Hole, 1987; Santos et al., 1998; Malmberg and Yaksh, 1992). Furthermore, NSAIDs can decrease, depending on the dose, the late phase of formalin-induced licking (Malmberg and Yaksh, 1992; Santos et al., 1998). Nevertheless, our result showed that DE, BE and AE of $P$. harmala, administered intraperitoneally, produce an equal gradual inhibition of the two phases of the formalin test in mice (central and inflammatory nociception). Hence, it seemed that the effect of dichloromethane, butanolic and aqueous extracts of $P$. harmala on the two phases demonstrated that they have active analgesic principles acting both centrally (inhibition of stimulation of the leg nociceptors) and peripherally (anti-inflammatory action by inhibition of $\mathrm{COX}$ and thus of prostaglandin synthesis). In the follow test (Hot-plate), the $\mathrm{DE}, \mathrm{BE}$ and $\mathrm{AE}$ of $P$. harmala administered intraperitoneal injection increase significantly the delay time for jumping as a function of the dose. However, intracerebroventricular administration exert antinociceptive effect only for DE and BE extracts (60 $\mu \mathrm{g} / \mathrm{kg}$ ). Seemingly, this effect depends mainly on the central mechanism, which performs an essential function in the endogenous opioid (Thompson, 1990). Although this test has demonstrated that it is adequate for the assessment of centrally acting analgesics, it is not appropriate for the evaluation of peripherally acting analgesics and has been shown to be valid even in the presence of substantial impairment of motor performance (Woolfe and Macdonald, 1994; Plummer et al., 1991). Results indicate that the analgesic action of the dichloromethane, butanolic and aqueous extracts of $P$. harmala is possibly related to a central mechanism. Our study, morphine, a centrally acting analgesic medicament (Heidari and Darban, 1998; Hajhashemi et al., 2002), generated a stronger analgesic response than the extracts of $P$. harmala in formalin and hot plate tests.

These extracts of $P$. harmala contain sterols, flavonoids, alkaloids, tannin and anthraquinones which have been demonstrated to provide analgesic activity in other herbal extracts (Duke, 1992). Accordingly, it could be suggested that the antinociceptive effect of $P$. harmala extracts might be caused by their content of previous active constituents.

In support of our suggestion, several data indicate that these compounds have a peripheral analgesic activity. Camila et al., (2020) states that both quercetin and Rutin stop pain through activation of cGMP/PKG/ATP-sensitive potassium channel pathways in neurons and by inhibiting $N F-\kappa B$ and inducing activation of Nrf2 in immune cells. Furthermore, the in vivo findings demonstrate that Vitexin decreases capsaicin-induced pain behavior, which indicates that part of the analgesic effect of Vitexin is related to the inhibition of TRPV1 activation (Tian et al., 2016). The analgesic effects of Vitexin seemed to be mediated by opioid-related mechanisms since delta, mu and $\kappa$ - opioid receptor antagonists reversed the analgesic effects of this flavonoid (Demir and Can, 2013).

The alkaloids of $P$. harmala have a broad spectrum of pharmacological acts in the central nervous system, for example convulsive or anticonvulsive actions (Loew et al., 1985), tremorogenesis (Poirier et al., 1966) and binding to diverse receptors, including 5-HT receptors and the benzodiazepine binding site of GABA (Lamarre and Puil, 1974; Rommelspacher et al., 1985; 1980).

Other studies have shown that flavonoids and alkaloids are capable to cross the blood-brain barrier and by several mechanisms, including the effect on GABA receptors, opioid receptors and alpha-adrenergic receptors, can block the enzymes implicated in inflammation and pain in several different parts of the nervous system, which includes the ventral spinal cord (medulla Rostral ventrolateral), alpha-adrenergic receptors and GABA. Stimulation of this receptor can induce analgesia (Taherianfard et al., 2018; Taherianfard and Karamifard, 2018; Bahmani et al., 2014).

Additional research, however, is needed to gain a better understanding of these mechanisms. We suggest that future efforts to improve analgesia should focus on the pharmacological response of active compounds both in vivo and that their detailed mechanisms be well illustrated, for example the involvement of the 5HT receptor, the opioid receptor and the GABAA/benzodiazepine or adenosine receptors in their analgesic effects.

\section{Conclusion}

In summary, current findings indicate for the first time that the $\mathrm{DE}, \mathrm{BE}$ and $\mathrm{AE}$ of $P$. harmala $L$. induce a dose-dependent antinociceptive action in animals, which is parallel to the traditional use of this plant. The study of the mechanism which produces $\mathrm{ED}, \mathrm{BE}$ and $\mathrm{AE}$ to induce analgesia is still unclear, but pharmacological, toxicological and chemical studies are in progress in order to characterize the mechanism(s) behind the 
analgesic action and also to identify the active ingredients present in $\mathrm{DE}, \mathrm{BE}$ and $\mathrm{AE}$ of $P$. harmala and are needed for use of this plant as an official herbal drug in clinical use. In addition, the antinociceptive effect showed in the current study supports, at least in part, the ethnomedical uses of this plant.

\section{Acknowledgement}

We sincerely thanks Mr. Regragui Abderazzak for his help in giving animals and drugs.

\section{Authors Contributions}

All authors participated in all experiments, coordinated the data-analysis and contributed to the writing of the manuscript.

\section{Ethics}

This article is originally from the authors works. The corresponding author confirms that all of the other authors have read and approved the manuscript and no ethical issues involved.

\section{References}

Aslam, N., Wani, A. A., Nawchoo, I. A., \& Bhat, M. A. (2014). Distribution and medicinal importance of Peganum harmala. A review. Int J Adv Res, 2(2), 751-755.

Aydin, S., Demir, T., Öztürk, Y., \& Başer, K. H. C. (1999). Analgesic activity of Nepeta italica L. Phytotherapy Research: An International Journal Devoted to Pharmacological and Toxicological Evaluation of Natural Product Derivatives, 13(1), 20-23. https://doi.org/10.1002/(SICI)10991573(199902)13:1<20::AID-PTR380>3.0.CO;2-J

Bahmani, M., Shirzad, H., Majlesi, M., Shahinfard, N., \& Rafieian-Kopaei, M. (2014). A review study on analgesic applications of Iranian medicinal plants. Asian Pacific journal of tropical medicine, 7, S43-S53. https://doi.org/10.1016/S1995-7645(14)60202-9

Bellakhdar, J. (1997). La pharmacopée marocaine traditionnelle. Médicine Arabe Ancienne et Savoirs Populaires, 189.

Bensalem, S., Soubhye, J., Aldib, I., Bournine, L., Nguyen, A.T., Vanhaeverbeek, M., Rousseau, A., Boudjeltia, K.Z., Sarakbi, A., Kauffmann, J.M. (2014). Inhibition of myeloperoxidase activity by the alkaloids of Peganum harmala L.(Zygophyllaceae). Journal Ethnopharmacology, 154, 361-369. https://doi.org/10.1016/j.jep.2014.03.070
Berrougui, H., López Lázaro, M., Martín Cordero, C., Mamouchi, M., Ettaib, A., \& Herrera González, M. D. (2005). Cytotoxic activity of methanolic extract and two alkaloids extracted from seeds of Peganum harmala L. Journal of Natural Remedies, 5 (1), 41-45.

Blumenthal, M., Goldberg, A., \& Brinckmann, J. (2000). Herbal medicine. Expanded commission E monographs. Integrative Medicine Communications.

Bournine, L., Bensalem, S., Fatmi, S., Bedjou, F., Mathieu, V., Iguer-Ouada, M.,... \& Duez, P. (2017). Evaluation of the cytotoxic and cytostatic activities of alkaloid extracts from different parts of Peganum harmala L.(Zygophyllaceae). European Journal of Integrative Medicine, 9, 91-96. https://doi.org/10.1016/j.eujim.2016.10.002

Camila, R., F., Thacyana, T. C., Marília, F. M., Nayara, A.A., \& Fernanda, S. R. O. (2020). Therapeutic Potential of Flavonoids in Pain and Inflammation: Mechanisms of Action, Pre-Clinical and Clinical Data, and Pharmaceutical Development. Molecules. 25: 762. https://doi.org/10.3390/molecules25030762

Cao, R., Peng, W., Wang, Z., \& Xu, A. (2007). B Carboline alkaloids: biochemical and pharmacological functions. Curr. Med. Chem. 14, 479-500. https://doi.org/10.2174/092986707779940998

Cervero, F., \& Laird, J. M. (1999). Visceral pain. The Lancet, 353(9170), 2145-2148. https://doi.org/10.1016/S0140-6736(99)01306-9

Chemli, R. (1991). Peganum harmala L: a poisonous plant of North Africa. Veterinary and Human Toxicology, 33(3), 276-277.

Chen, Y. F., Tsai, H. Y., \& Wu, T. S. (1995). Antiinflammatory and analgesic activities from roots of Angelica pubescens. Planta Medica, 61(01), 2-8. https://doi.org/10.1055/s-2006-957987

Coderre, T. J., \& Melzack, R. (1992). The contribution of excitatory amino acids to central sensitization and persistent nociception after formalin-induced tissue injury. Journal of Neuroscience, 12(9), 3665-3670. https://doi.org/10.1523/JNEUROSCI.12-0903671.1992

Coderre, T. J., Vaccarino, A. L., \& Melzack, R. (1990). Central nervous system plasticity in the tonic pain response to subcutaneous formalin injection. Brain Research, 535(1), 155-158. https://doi.org/10.1016/0006-8993(90)91835-5

Collier, H. O., Dinneen, L. C., Johnson, C. A., \& Schneider, C. (1968). The abdominal constriction response and its suppression by analgesic drugs in the mouse. British Journal of Pharmacology and Chemotherapy, 32(2), 295.

https://doi.org/10.1111/j.1476-5381.1968.tb00973.x 
Debray, M., Jacquemin, H., \& Razafindrambao, R. (1971). Contribution to the inventory of medicinal plants of Madagascar.

Demir, O. U., and O.D. Can, 2013. Anti-nociceptive effect of vitexin mediated by the opioid system in mice. Pharm. Biochem. Behav. 109: 23-30. https://doi.org/10.1016/j.pbb.2013.04.014

Deraedt, R., Jouquey, S., Delevallée, F., \& Flahaut, M. (1980). Release of prostaglandins $\mathrm{E}$ and $\mathrm{F}$ in an algogenic reaction and its inhibition. European journal of pharmacology, 61(1), 17-24. https://doi.org/10.1016/0014-2999(80)90377-5

Derakhshanfar, A., Oloumi, M. M., \& Mirzaie, M. (2010). Study on the effect of Peganum harmala extract on experimental skin wound healing in rat: pathological and biomechanical findings. Comparative clinical pathology, 19(2), 169-172. https://doi.org/10.1007/s00580-009-0848-1

Duke, J. A. (1992). Handbook of biologically active phytochemicals and their activities. CRC Press, Inc..

Farouk, L., Laroubi, A., Aboufatima, R., Benharref, A., \& Chait, A. (2008). Evaluation of the analgesic effect of alkaloid extract of Peganum harmala L.: possible mechanisms involved. Journal of ethnopharmacology, 115(3), 449-454. https://doi.org/10.1016/j.jep.2007.10.014

Farouk, L., Laroubi, A., Ouachrif, A., Aboufatima, R., Benharref, A., \& Chait, A. (2009). Antinociceptive activity of various extracts of Peganum harmala L. and possible mechanism of action.

Grumbach, L. E. O. N. A. R. D. (1966). The prediction of analgesic activity in man by animal testing. In Pain (pp. 163-182). Little Brown Boston.

Hajhashemi, V., Ghannadi, A., \& Pezeshkian, S. K. (2002). Antinociceptive and anti-inflammatory effects of Satureja hortensis L. extracts and essential oil. Journal of ethnopharmacology, 82(2-3), 83-87. https://doi.org/10.1016/S0378-8741(02)00137-X

Heidari, M. R., \& Darban, M. (1998). Evaluation of analgesic effect of Mellissia officinalis extract by Tail-flick test in mice.

Herraiz, T., González, D., Ancín-Azpilicueta, C., Arán, V. J., \& Guillén, H. (2010). $\beta$-Carboline alkaloids in Peganum harmala and inhibition of human monoamine oxidase (MAO). Food and Chemical Toxicology, 48(3), 839-845. https://doi.org/10.1016/j.fct.2009.12.019

Hunskaar, S., \& Hole, K. (1987). The formalin test in mice: dissociation between inflammatory and noninflammatory pain. Pain, 30(1), 103-114. https://doi.org/10.1016/0304-3959(87)90088-1

Hunskaar, S., Berge, O. G., \& Hole, K. (1986). Dissociation between antinociceptive and antiinflammatory effects of acetylsalicylic acid and indomethacin in the formalin test. Pain, 25(1), 125-132. https://doi.org/10.1016/03043959(86)90014-X
Kumar, M. P., Joshi, S. D., Kulkarni, V. H., \& Savant, C. (2015). Phytochemical screening and evaluation of analgesic, anti-inflammatory activities of Peganum harmala Linn., seeds in rodents. Journal of Applied Pharmaceutical Science, 5(05), 052-055. https://doi.org/10.7324/JAPS.2015.50510

Lamarre, Y., \& Puil, E. (1974). Induction of rhythmic activity by harmaline. Canadian Journal of Physiology and Pharmacology, 52(4), 905-908. https://doi.org/10.1139/y74-118

Li, S., Cheng, X., \& Wang, C. (2017). A review on traditional uses, phytochemistry, pharmacology, pharmacokinetics and toxicology of the genus Peganum. Journal of ethnopharmacology, 203, 127-162. https://doi.org/10.1016/j.jep.2017.03.049

Li, W.K., 1996. Extraction of alkaloids from Peganum harmala L. and Study on their antihydatid chemical composition. J. Lanzhou. Med. Coll. 22, 16-18

Loew, G. H., Nienow, J., Lawson, J. A., Toll, L., \& Uyeno, E. T. (1985). Theoretical structure-activity studies of beta-carboline analogs. Requirements for benzodiazepine receptor affinity and antagonist activity. Molecular pharmacology, 28(1), 17-31.

Mabika, K. (1983). Medicinal plants and traditional medicine of Kasai-Occidental.

Malmberg, A. B., \& Yaksh, T. L. (1992). Antinociceptive actions of spinal nonsteroidal antiinflammatory agents on the formalin test in the rat. Journal of Pharmacology and Experimental Therapeutics, 263(1), 136-146.

Moloudizargari, M., Mikaili, P., Aghajanshakeri, S., Asghari, M. H., \& Shayegh, J. (2013). Pharmacological and therapeutic effects of Peganum harmala and its main alkaloids. Pharmacognosy reviews, 7(14), 199. https://doi.org/10.4103/09737847.120524

Monsef, H. R., Ghobadi, A., Iranshahi, M., \& Abdollahi, M. (2004). Antinociceptive effects of Peganum harmala L. alkaloid extract on mouse formalin test. J Pharm Pharm Sci, 7(1), 65-9.

Moradi, M. T., Karimi, A., Rafieian-Kopaei, M., \& Fotouhi, F. (2017). In vitro antiviral effects of Peganum harmala seed extract and its total alkaloids against Influenza virus. Microbial pathogenesis, 110, 42-49. https://doi.org/10.1016/j.micpath.2017.06.014

Odebiyi, O. O., \& Sofowora, E. A. (1978). Phytochemical screening of Nigerian medicinal plants II. Lloydia, 41(3), 234.

Olmedo, G. M., Cerioni, L., González, M. M., Cabrerizo, F. M., Rapisarda, V. A., \& Volentini, S. I. (2017). Antifungal activity of $\beta$-carbolines on Penicillium digitatum and Botrytis cinerea. Food microbiology, 62, 9-14. https://doi.org/10.1016/j.fm.2016.09.011 
Paris, R., \& Moyse-Mignon, H. (1965). Précis de matière médicale: par RR Paris et H. Moyse. Masson.

Paulino, N., Dantas, A. P., Bankova, V., Longhi, D. T., Scremin, A., de Castro, S. L., \& Calixto, J. B. (2003). Bulgarian propolis induces analgesic and anti-inflammatory effects in mice and inhibits in vitro contraction of airway smooth muscle. Journal of Pharmacological Sciences, 93(3), 307-313. https://doi.org/10.1254/jphs.93.307

Paxinos, G., \& Watson, C. (2006). The rat brain in stereotaxic coordinates: hard cover edition. Elsevier.

Piccinelli, D., \& Silvestrini, B. (1969). Experimental research on the analgesic activity of levallorphan. Pharmacological Research Communications, 1(1), 100-107. 6989(69)80032-9

Plummer, J. L., Cmielewski, P. L., Gourlay, G. K., Owen, H., \& Cousins, M. J. (1991). Assessment of antinociceptive drug effects in the presence of impaired motor performance. Journal of pharmacological methods, 26(1), 79-87. https://doi.org/10.1016/0160-5402(91)90057-C

Poirier, L. J., Sourkes, T. L., Bouvier, G., Boucher, R., \& Carabin, S. (1966). Striatal amines, experimental tremor and the effect of harmaline in the monkey. Brain, 89(1), 37-52. https://doi.org/10.1093/brain/89.1.37

Thompson, E. B. (1990). Drug bioscreening: drug evaluation techniques in pharmacology. Wiley-VCH.

Reichert, J. A., Daughters, R. S., Rivard, R., \& Simone, D. A. (2001). Peripheral and preemptive opioid antinociception in a mouse visceral pain model. Pain, 89(2-3), 221-227. https://doi.org/10.1016/S0304-3959(00)00365-1

Rizk, A. M., Am, R., Al Nagdy, S. A., \& El Missiry, M. M. (1982). Constituents of plant growing in Qatar.

Rommelspacher, H., Brüning, G., Susilo, R., Nick, M., \& Hill, R. (1985). Pharmacology of harmalan (1methyl-3, 4-dihydro- $\beta$-carboline). European journal of pharmacology, 109(3), 363-371. https://doi.org/10.1016/0014-2999(85)90397-8

Rommelspacher, H., Nanz, C., Borbe, H. O., Fehske, K. J., Müller, W. E., \& Wollert, U. (1980). 1Methyl- $\beta$-carboline (harmane), a potent endogenous inhibitor of benzodiazepine receptor binding. Naunyn-Schmiedeberg's archives of pharmacology, 314(1), 97-100. https://doi.org/10.1007/BF00498436

Saeed, S. A., Farnaz, S., Simjee, R. U., \& Malik, A. (1993). Triterpenes and B-sitosterol from piper betle: isolation, antiplatelet and anti-inflammatory effects. Biochemical Society Transactions, 21(4), 462S-462S. https://doi.org/10.1042/bst021462s
Santos, A. R. S., \& Calixto, J. B. (1997). Further evidence for the involvement of tachykinin receptor subtypes in formalin and capsaicin models of pain in mice. Neuropeptides, 31(4), 381-389. https://doi.org/10.1016/S0143-4179(97)90075-5

Santos, A. R. S., Vedana, E. M. A., \& De Freitas, G. A. G. (1998). Antinociceptive effect of meloxicam, in neurogenic and inflammatory nociceptive models in mice. Inflammation Research, 47(7), 302-307. https://doi.org/10.1007/s000110050333

Schmauss, C., \& Yaksh, T. L. (1984). In vivo studies on spinal opiate receptor systems mediating antinociception. II. Pharmacological profiles suggesting a differential association of mu, delta and kappa receptors with visceral chemical and cutaneous thermal stimuli in the rat. Journal of Pharmacology and Experimental Therapeutics, 228(1), $1-12$. https://jpet.aspetjournals.org/content/228/1/1.short

Shibata, M., Ohkubo, T., Takahashi, H., \& Inoki, R. (1989). Modified formalin test: characteristic biphasic pain response. pain, 38(3), 347-352. https://doi.org/10.1016/0304-3959(89)90222-4

Taherianfard, M., \& Karamifard, M. (2018). Evaluation of the GABAA receptor on pain sensitivity in male rat pretreated with Valeriana officinalis extract using formalin test. Physiology and Pharmacology, 22(2), 118-123.

Taherianfard, M., Farhangdareshuri, F., \& Shomali, T. (2018). Interactive effect of aqueous-alcoholic extract of ginger as well as GABAA receptor agonist and antagonist on pain sensitivity in male rats. Physiology and Pharmacology, 22(4), 247-253.

Tian, R., Yang, W., Xue, Q., Gao, L., Huo, J., Ren, D., \& Chen, X. (2016). Rutin ameliorates diabetic neuropathy by lowering plasma glucose and decreasing oxidative stress via Nrf2 signaling pathway in rats. European journal of pharmacology, 771, 84-92. https://doi.org/10.1016/j.ejphar.2015.12.021

Tjølsen, A., Berge, O. G., Hunskaar, S., Rosland, J. H., \& Hole, K. (1992). The formalin test: an evaluation of the method. Pain, 51(1), 5-17. https://doi.org/10.1016/0304-3959(92)90003-T

Tornos, M. P., Sáenz, M. T., García, M. D., \& Fernández, M. A. (1999). Antinociceptive effects of the tubercles of Anredera leptostachys. Journal of ethnopharmacology, 68(1-3), 229-234. https://doi.org/10.1016/S0378-8741(99)00098-7

Trease, G. E., \& Evans, W. C. (1983). Textbook of Pharmacognosy. (Balliere. Tindall, London, 57-59.

YH, T. S., Mak, I., \& Dickens, B. F. (1991). Antioxidative properties of harmane and $\beta$-carboline alkaloids. Biochemical pharmacology, 42(3), 459-464. https://doi.org/10.1016/0006-2952(91)90305-O 
Turner, R. A., \& Hebban, P. (1965). Analgesics: Screening methods in pharmacology. Academic Press, New York, 100. https://doi.org/10.1016/B978-1-4832-32669.50012-8

Vogel, H. G., \& Vogel, W. H. (1997). Analgesic, antiinflammatory, and antipyretic activity. In Drug discovery and evaluation (pp. 360-420). Springer, Berlin, Heidelberg. https://doi.org/10.1007/978-3662-03333-3_8
Woolfe, G., \& MacDonald, A. D. (1944). The evaluation of the analgesic action of pethidine hydrochloride (Demerol). Journal of Pharmacology and Experimental Therapeutics, 80(3), 300-307. https://jpet.aspetjournals.org/content/80/3/300.short 